OPEN ACCESS

Edited by:

Zhenjun Ma,

University of Wollongong, Australia

Reviewed by:

Jiachen Zhang,

California Air Resources Board, United States

Haoshan Ren,

City University of Hong Kong, China

*Correspondence: Ming Chian Yew yewmc@utar.edu.my

Specialty section: This article was submitted to Indoor Environment

a section of the journal Frontiers in Built Environment

Received: 13 December 2020

Accepted: 11 January 2021

Published: 19 February 2021

Citation:

Yew MC, Yew MK, Ho ML and Saw LH (2021) Integration of Lightweight Foam Concrete Roof, Moving-Air-Cavity, and

Solar-Powered Fans for Attic

Temperature Reduction.

Front. Built Environ. 7:641041 doi: 10.3389/fbuil.2021.641041

\section{Integration of Lightweight Foam Concrete Roof, Moving-Air-Cavity, and Solar-Powered Fans for Attic Temperature Reduction}

\author{
Ming Chian Yew ${ }^{1 *}$, Ming Kun Yew ${ }^{2}$, Mun Ling Ho ${ }^{1}$ and Lip Huat Saw ${ }^{1}$ \\ ${ }^{1}$ Department of Mechanical and Material Engineering, Lee Kong Chian Faculty of Engineering and Science, Universiti Tunku Abdul \\ Rahman, Cheras, Malaysia, ${ }^{2}$ Department of Civil Engineering, Lee Kong Chian Faculty of Engineering and Science, Universiti \\ Tunku Abdul Rahman, Cheras, Malaysia
}

This paper presents a novel cool roof technology system that promotes both passive and active cooling methods in reducing the attic temperature of the building. The project aimed to evaluate the effect of various roof model designs on the heating load to establish the capacity of a cooling roof system by maintaining the thermal comfort level for occupants in the buildings. There are four main components in constructing the cool roof models: 1) metal deck roof, 2) lightweight foam concrete roof, 3) moving-air-cavity (MAC) ventilation, and 4) solar-powered fan. Four small-scale cool roof models were built to evaluate the performance of each cool roof design. The performances of the roof surface and attic temperatures of each designed cool roof models were compared with the conventional metal deck roof. The roof models were conducted indoors by using halogen spotlights. The result of the Roof Design IV with the integration of lightweight foam concrete, MAC, and solar-powered fans has effectively reduced the attic temperature by $6.0^{\circ} \mathrm{C}$ compared with the normal roof model (Roof Design I). As a result, this integrated cool roof design comprises the ability to enhance the comfortability of occupants toward long-term sustainable development with the utilization of renewable energy to protect the natural environment.

Keywords: solar, moving-air-cavity, attic temperature, sustainable building, global warming

\section{INTRODUCTION}

Many recent studies have focused on green building with interest in cool roof technology. A cool roof is a roof that absorbs less heat and reflects more sunlight than a standard roof, lowering roof temperature and transferring less heat into the space of the attic and room. While the benefits of cool roofs are more significant in hotter climates, their advantages can also extend into the Western Hemisphere, tropical countries including Mexico, all of Central America, all of the Caribbean islands from just south of Nassau in the Bahamas, and the top half of South America for various commercial and industrial buildings (Bianchini and Hewage, 2012).

Malaysia is a developing Southeast Asian country, which is located just north of the Equator. Malaysia's economic growth had greatly increased the country's energy consumption. The highest daily electricity demand for Malaysia hit 17,788 MW on april 19, 2016 after a record of 17,175 MW on March 9, 2016 (Hasan, 2017). The rise in the population of Malaysia has led to the increasing demand for residential housing and industrial buildings. Malaysia averagely will have $27^{\circ} \mathrm{C}$ in most 
of the cities. However, for East Malaysia, the temperature ranges from $23^{\circ} \mathrm{C}$ to a maximum temperature of $32^{\circ} \mathrm{C}$ (Ooi et al., 2020).

Most of the buildings in Malaysia were constructed close to each other especially in the city area, which causes poor ventilation between the buildings. Moreover, the hot climate results in a high indoor temperature when the solar radiation hits the roof and wall of the buildings, which increases the demand for air conditioners. The main component of a building that receives the most amount of solar radiation is the roof. The roof is located at the most high-up of a building and is covered by a gypsum ceiling board before the inner place of a house. In Malaysia, most general roof materials in the houses and factories are concrete roof tiles (85\%), clay roof files (10\%), and metal deck (5\%) (Yew et al., 2013). Additionally, a black roof surface temperature can exceed up to $87.8^{\circ} \mathrm{C}$ when exposed to full sunlight, especially in countries with hot climates (Yew et al., 2018).

For a building, the highest temperature takes place in the attic region. The attic region is the space below the roof and above the building's ceiling board. When the roof absorbs the solar radiation during the daytime, the heat is transferred into the attic region through conduction. The heat is then trapped inside the attic region due to the airtight design of the conventional roof. The prohibition of entering air of a conventional roof design is the main cause of high temperature recorded in the attic region. The heat is then transferred to the inner building, which results in a hot indoor atmosphere. The attic will always have higher temperature compared to the living space (Zhao et al., 2019).

A few cool roof systems were designed and developed by researchers to reduce the building's energy consumption on keeping the building cool (Romeo and Zinzi, 2013). A cool roof system is one of the modern substantial energy reduction approaches. When the overall temperature of the attic region is reduced, the temperature inside the building would be directly reduced, which causes the lowering of cooling load. A cool roof system promotes attic ventilation, the cool ambient air is being drawn in, and the hot trapped air is being drawn out. When the cool ambient air reaches the attic region and mixes with the air inside, the air temperature can be effectively reduced at day time, which results in a lower transfer of heat from the attic region to the living space (Zhao et al., 2019).

The cool roof system has a radiative surface, which facilitates the solar reflection. Moreover, the cool roof system consists of a few radiative air coolers linked in a parallel manner to promote heat transmission (Zhao et al., 2019). Overall, a cool roof is an upgraded roof design composed of passive and active cool roof systems (Yew and Yew, 2021). A cool roof can benefit the environment such as reducing the urban island effect with the cooler outside air, lessening power plant emissions by reducing air conditioning demand, which decreases the greenhouse gases and other air pollutants from the burned fossil fuels, and slowing climate change as cool roofs decrease heat absorbed on the Earth's surface (Macintyre and Heaviside, 2019). Most of the roofs in industrial buildings such as factories and warehouses are built using metal deck roofing that leads to rising of the roof, attic, and indoor temperatures when exposed to full sunlight in the afternoon. In this project, the designed cool roof roofing

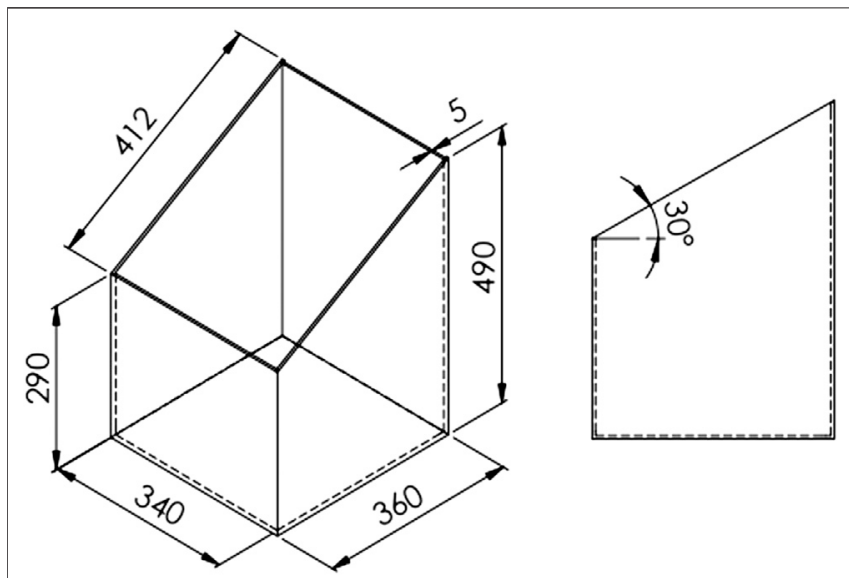

FIGURE 1 | The dimensions of basic cool roof model (all units in $\mathrm{mm}$ ).

technology system makes use of the solar-powered fan, moving-air-cavity (MAC), and lightweight foam concrete roofing to reduce the attic temperature toward an eco-friendly and sustainable roof design, which has not been studied by other researchers.

The main goal of this study is to evaluate a system that combines innovative lightweight foam concrete roof with aluminum tubes for cavity ventilation and solar-powered fan to optimize the performance of the novel roofing system in terms of heat reflection and heat rejection. The performance will be assessed by evaluating the various temperatures of the roof, aluminum channel, and attic. The aim will be to obtain lower attic temperatures that will result in a more comfortable living environment.

Four small-scale roof models representing the different roof system designs were built to evaluate the resistance to heat gain. Components that were tested included the lightweight foam concrete roof, MAC ventilation, and solar-powered fan. The performance of the four designs 1) metal deck roof coated with normal paint without MAC (Design I), 2) lightweight foam concrete without MAC (Design II), 3) combination of lightweight foam concrete with MAC (Design III), and 4) combination of lightweight foam concrete with MAC and solar-powered fan (Design IV) were studied and compared.

\section{EXPERIMENTAL DESIGN}

The basic model of the cool roof system is the attic region. The basic model was built by using Perspex of $5 \mathrm{~mm}$ thickness and covered by a metal deck roofing [dimensions: $450 \mathrm{~mm}(\mathrm{~L}) \times$ $380 \mathrm{~mm}(\mathrm{~W}) \times 1.5 \mathrm{~mm}$ (D)] with a thermal conductivity of $45.3 \mathrm{~W} / \mathrm{mK}$. The dimensions of the basic model were $340 \mathrm{~mm}$ in length, $360 \mathrm{~mm}$ in width, and $490 \mathrm{~mm}$ in height. Figure 1 shows the dimensions of the basic model with a roof area of $412 \mathrm{~mm}$ in length and $340 \mathrm{~mm}$ in width inclined at an angle $30^{\circ}$.

\subsection{Lightweight Foam Concrete Tile}

The lightweight foam concrete tile was constructed with a targeted density of $1,250 \mathrm{~kg} / \mathrm{m}^{3}$, and its thermal conductivity value is $0.61 \mathrm{~W} / \mathrm{m} . \mathrm{K}$. The base mix mass was $6.6 \mathrm{~kg}$, and the 


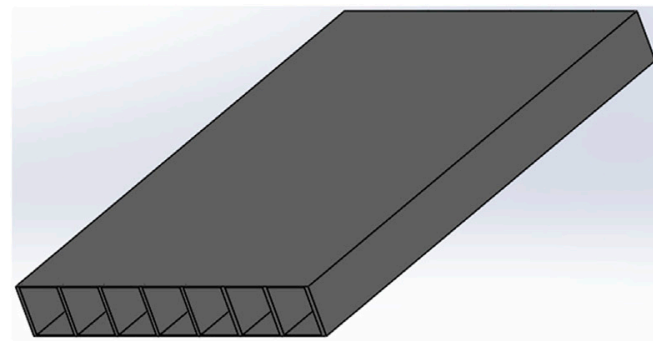

A

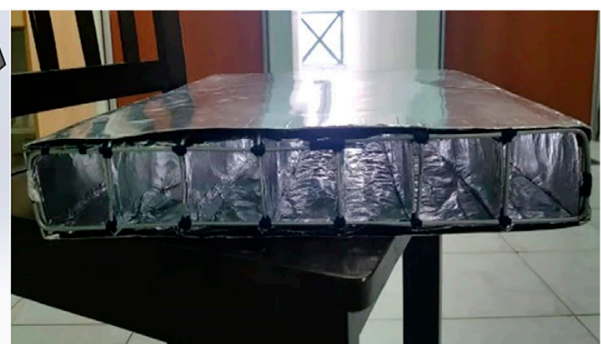

B

FIGURE 2 | The diagram of moving-air-cavity (MAC). (A) SolidWorks (B) Experimental.

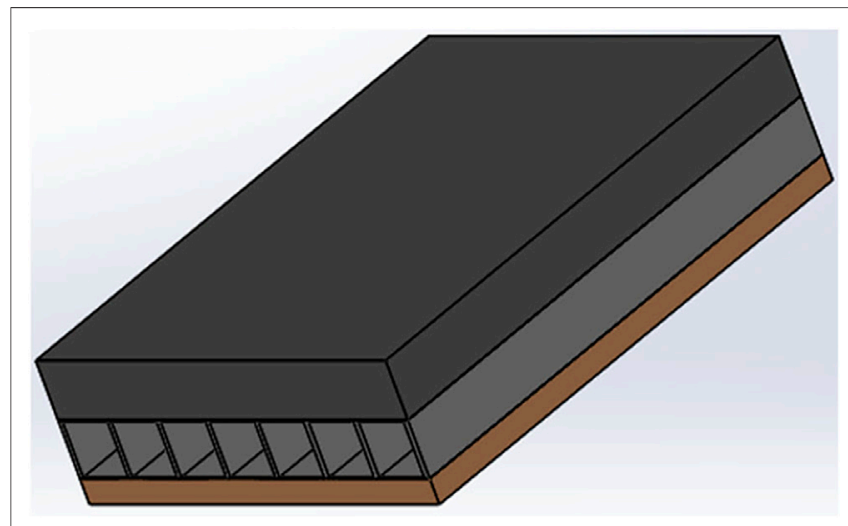

FIGURE 3 | The lightweight foam concrete roof with MAC ventilation.

foam density was $50 \mathrm{~kg} / \mathrm{m}^{3}$. The cement paste was added with $0.5 \%$ calcium stearate and $2.6 \%$ of eggshell. The final dimensions of lightweight foam concrete tile after curing was $460 \mathrm{~mm}$ in length, $360 \mathrm{~mm}$ in width, and $30 \mathrm{~mm}$ in height.

\subsection{Moving-Air-Cavity}

The MAC was located underneath the roof and above the attic region. The surface of the MAC was built with an aluminum sheet. The channel inside the MAC was built with aluminum foil as shown in Figure 2. The structure was supported by a steel rod.

The cavity, which is surrounded by aluminum foil acts as a heat radiant reflector. The thickness of lightweight foam concrete roof was $46 \mathrm{~mm}$. The design and dimension of MAC and lightweight foam concrete roof are presented in Figure 3.

Since the channels were separated into seven by aluminum foil and steel rod, the channels acted as the tubes for heat exchange to maintain the cool temperature in the attic. The air channel of $43 \mathrm{~mm}$ wide allowed $3 \mathrm{~mm}$ of tolerance when $40 \times 40$-mm-sized solar-powered fans were installed.

\subsection{Solar-Powered Fans}

Seven solar-powered fans of dimensions $4 \mathrm{~cm} \times 4 \mathrm{~cm}$ were connected horizontally and tied to a plastic mesh. The MAC accommodated seven channels to place solar-powered fans that were tilted $30^{\circ}$ from the vertical axis to align with the channel direction. The solar-powered fans were attached at the inlets of the MAC as shown in Figure 4. The fans were then connected to the solar panel for obtaining the power source from the halogen spotlights.

The air channel with uniform parallel design maximized the amount of air in the MAC. Air can act as a thermal insulation element to stop the heat conducted through the roof from transferring downward to the attic. The departmentalized design of MAC followed the dimension of solar-powered fans. It is to ensure that all the cool air induced by the solar-powered fans enter the MAC completely. Each solar-powered fan had an air channel to prevent the flow interruption from the other solarpowered fans, which slowed down the rate of airflow and the heat transfer.

\subsection{Halogen Spotlight Setup}

The halogen spotlight acted as a source of sunlight in this project. The temperature of the surrounding indoor air was nearly $30.5^{\circ} \mathrm{C}$ before the test. The lamp provided the necessary heat source for the roof warming and the light source for the solar panel. In this project, two $500-\mathrm{W}$ halogen spotlights were placed $45^{\circ}$ from the vertical axis and the distance of the lamps and roof surface was fixed at $30 \mathrm{~cm}$ as shown in Figure 5.

\subsection{Temperature Sensor Setup}

Four temperature sensors of K-type thermocouple were used at the assigned location and set up as shown in Figure 6. The first thermocouple A was taped using aluminum tape on the roof surface for all the roof designs to measure the roof temperature. The second thermocouple B was placed $200 \mathrm{~mm}$ vertically downwards from thermocouple $\mathrm{A}$, and it was used to measure the attic temperature.

Then, the third thermocouple $\mathrm{C}$ was used to measure the surrounding indoor air temperature before conducting the test. D was placed at the MAC. Last, the thermocouple D was used at all roof designs except roof Designs I and II. The data were recorded every $1 \mathrm{~min}$ for a total experiment duration of $30 \mathrm{~min}$.

\subsection{Roof Models Setup}

The experimental setup was divided into roof setup, halogen spotlight setup, and temperature sensor setup. This project had four roof models, the normal metal deck (Design I), foam concrete roof (Design II), foam concrete roof with MAC 


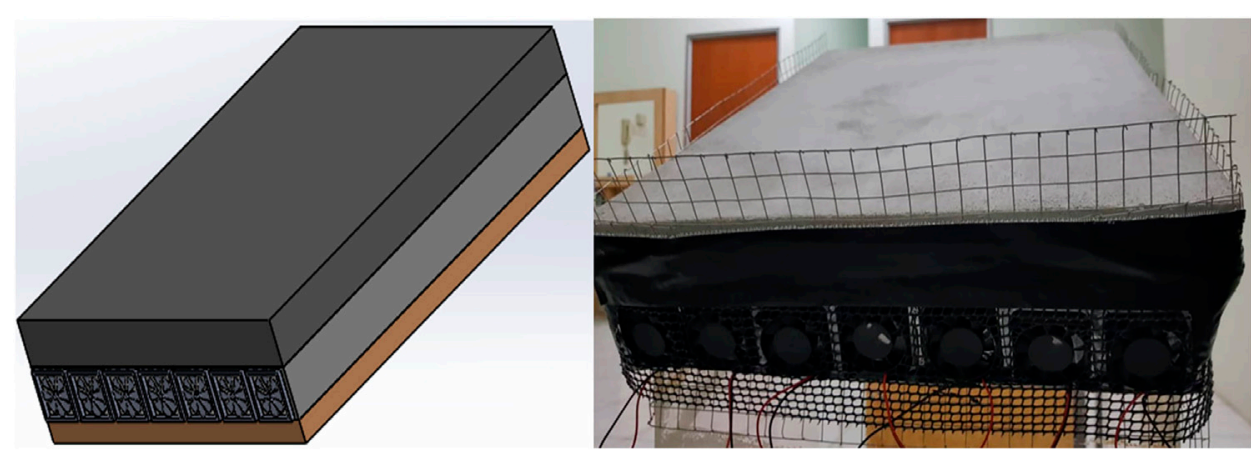

FIGURE 4 | The solar-powered fans attached to MAC (left) SolidWorks (right) experimental.

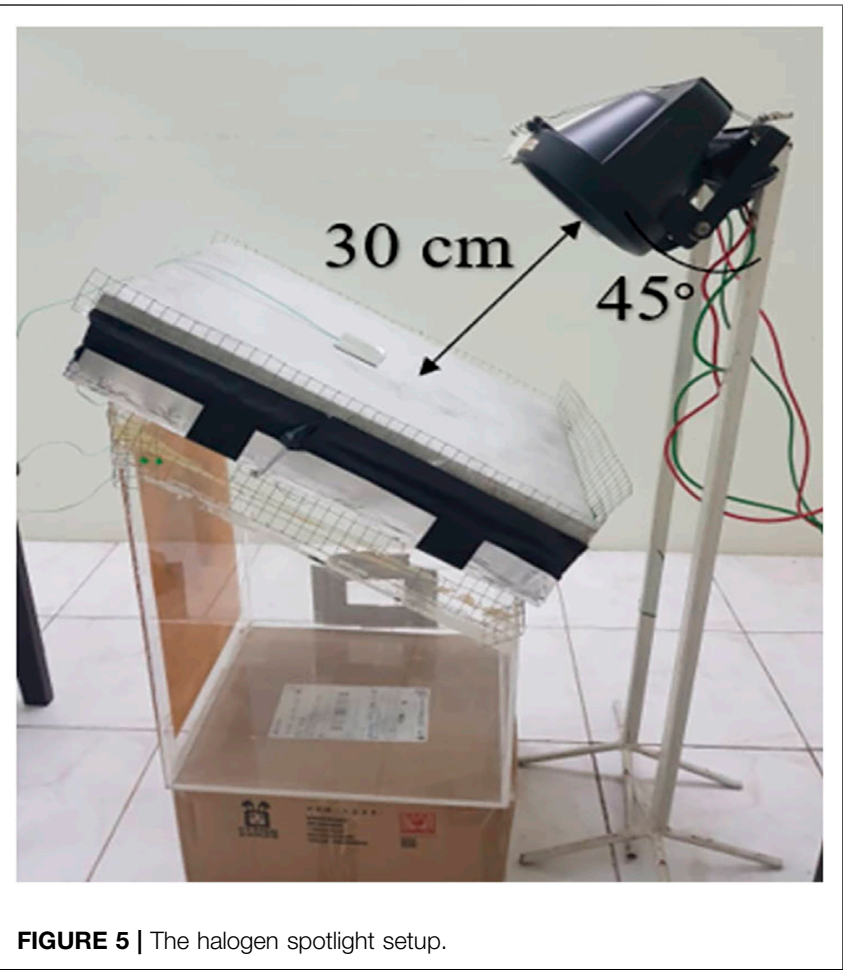

(Design III), and foam concrete roof with MAC and solarpowered fans (Design IV), and are shown in Figure 7. The four roof models were conducted, and their roof performances and attic temperatures were compared.

\subsection{Computation of Solar Reflectance in Cool Roof}

The heat transfer process is important in the analysis of a cool roof system. The heat emitted by the Sun radiation reach the roof surface and enter the attic region by conduction process.

Figure 8 shows the mechanism of heat transfer in a cool roof system. The practice of two control volumes, $C V_{1}$ and $C V_{2}$, is used to determine the heat transfer mechanism. From the $C V_{1}$ control volume enclosed area, the heat comes in from the ambient

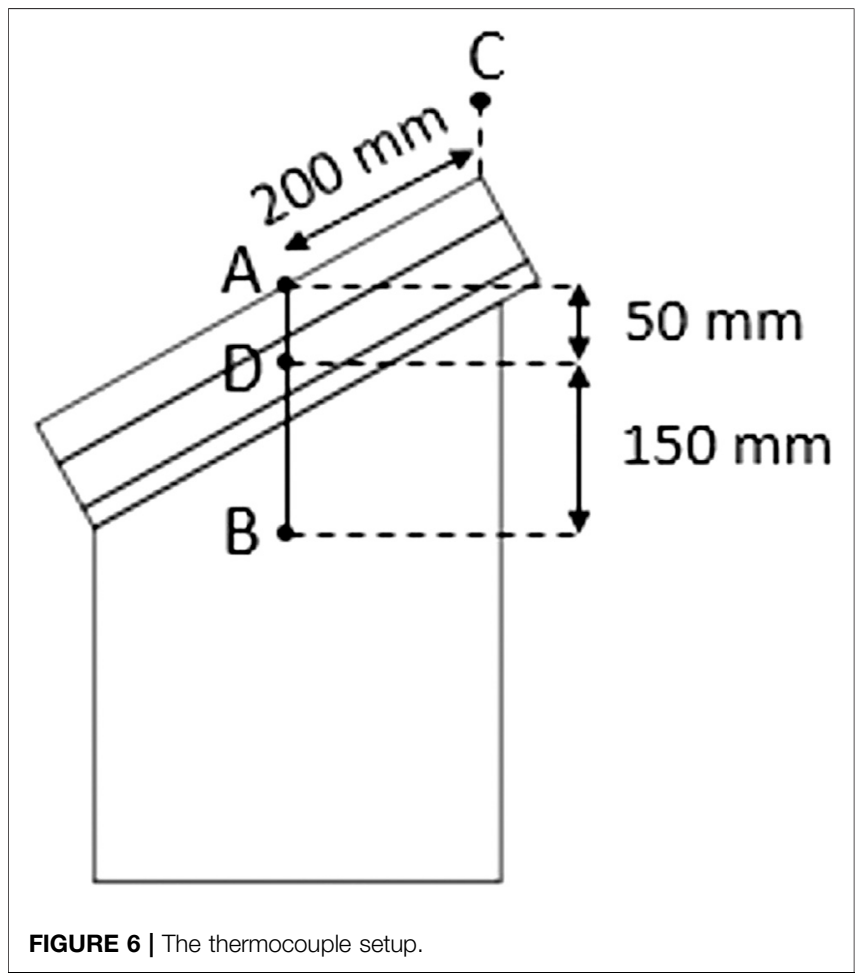

surrounding to the thermal reflective coating and metal deck roof, while some heat is reflected away by radiation and convection and enters the $C V_{2}$. From the $C V_{2}$ control volume enclosed area, the heat that is going through the $C V_{1}$ control volume now acts as the heat input for the $C V_{2}$ control volume; the heat then continues to enter and is released from $\mathrm{CV}_{2}$ (Yew et al., 2018).

The flow of heat from the ambient surrounding to the roof, attic, and inner space is proved by the second law of thermodynamics. The second law of thermodynamics declared the moving of heat from high temperature to low temperature. Equations 1, 2 are generated by the conservation of energy at control volumes $C V_{1}$ and $C V_{2}$, respectively. The conservation of energy in this case is the same amount of heat input and heat output.

$$
Q_{s}=Q_{\text {Rad, out }}+Q_{\text {Conv, out }}+Q_{\text {cond }}
$$



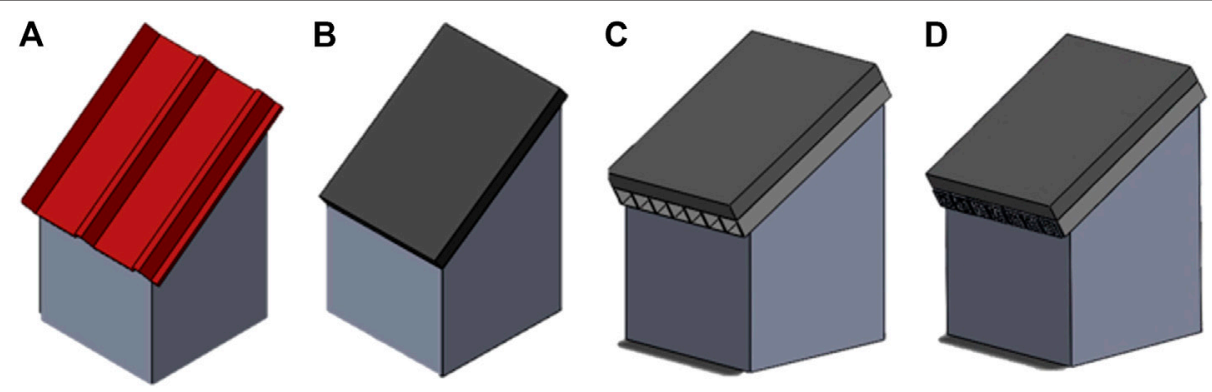

FIGURE 7 | The roof model designs (A) | (B) || (C) III, and (D) IV.

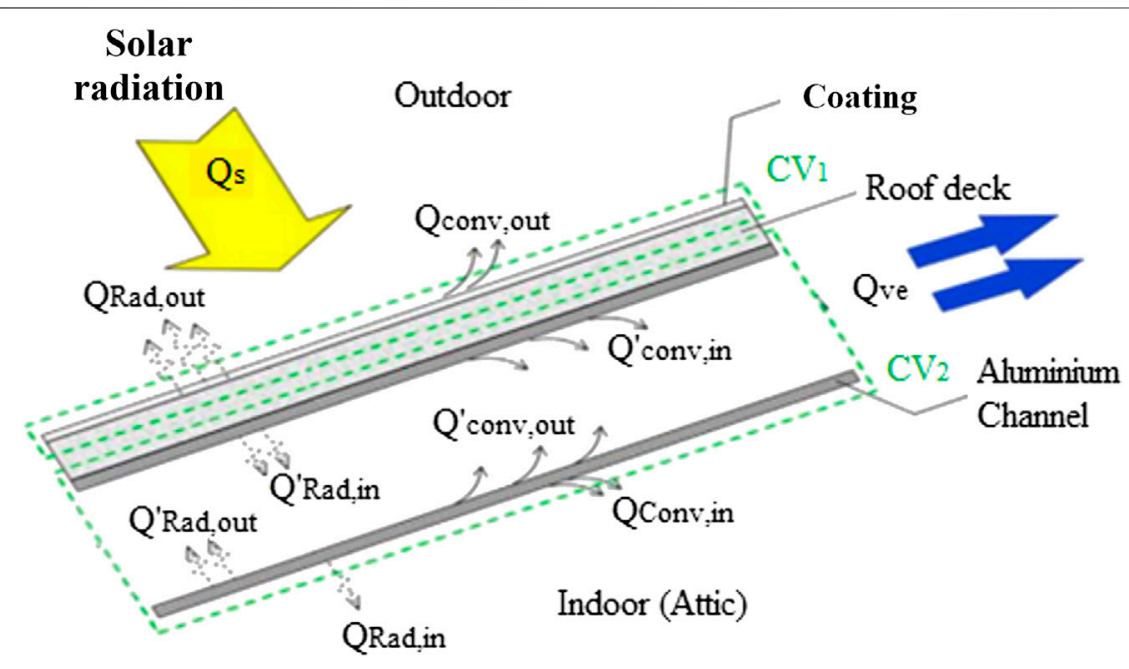

FIGURE 8 | The mechanism of heat transfer of the cool roof system.

where,

$Q_{s}=$ the heat emitted from the halogen light bulb that shined on roof, $\mathrm{W}$

$Q_{\text {Rad,out }}=$ is the radiation heat that reflected away from the roof coating, $\mathrm{W}$

$Q_{\text {Conv, out }}=$ the convection heat that reflected away from roof, W

$Q_{\text {Cond }}=$ the conduction heat passing through the metal deck roof, W

$$
Q_{\text {Cond }}=Q_{\text {Rad, in }}+Q_{\text {Conv, in }}+Q_{v e}
$$

where,

$Q_{\text {Cond }}=$ the conduction heat entering the cavity from the metal deck roof, $\mathrm{W}$

$Q_{\text {Rad,in }}=$ the radiation heat entering the attic region, $\mathrm{W}$

$Q_{\text {Conv, in }}=$ the convection heat entering the attic region, $\mathrm{W}$

$Q_{v e}=$ the heat removed due to the improved moving-aircavity, $\mathrm{W}$
From Equation 1, the heat absorbed by the roof due to the heat emitted from the Sun can be reflected away by the reflectivity of the roof coating by radiation and convection. The presence of coating prevents the full amount of heat absorbed by the roof from transferring into the roof cavity by conduction of the metal deck.

From Equation 2, the heat that is not reflected away at the first control volume now acts as the heat input to the roof cavity. The heat then dissipated to the attic region by radiation and convection. By the design of the moving-air-cavity, a portion of the heat is removed instead of dissipated into the attic region. The moving-air-cavity, the aluminum channel, provides a space for the heat to move up and finally be removed to the surroundings by the second law of thermodynamics. The heat removal rate of the moving-air-cavity is expressed in Eq. 3 .

$$
Q_{v e}=\dot{m} C_{p}\left(T_{\text {out }}-T_{\text {in }}\right)
$$

where,

$\dot{m}=$ the mass flow rate of air inside the moving-air-cavity, the aluminum channel, $\mathrm{kg} / \mathrm{s}$

$C_{p}=$ the specific heat at atmospheric pressure, $\mathrm{J} / \mathrm{kg} \cdot \mathrm{K}$ 


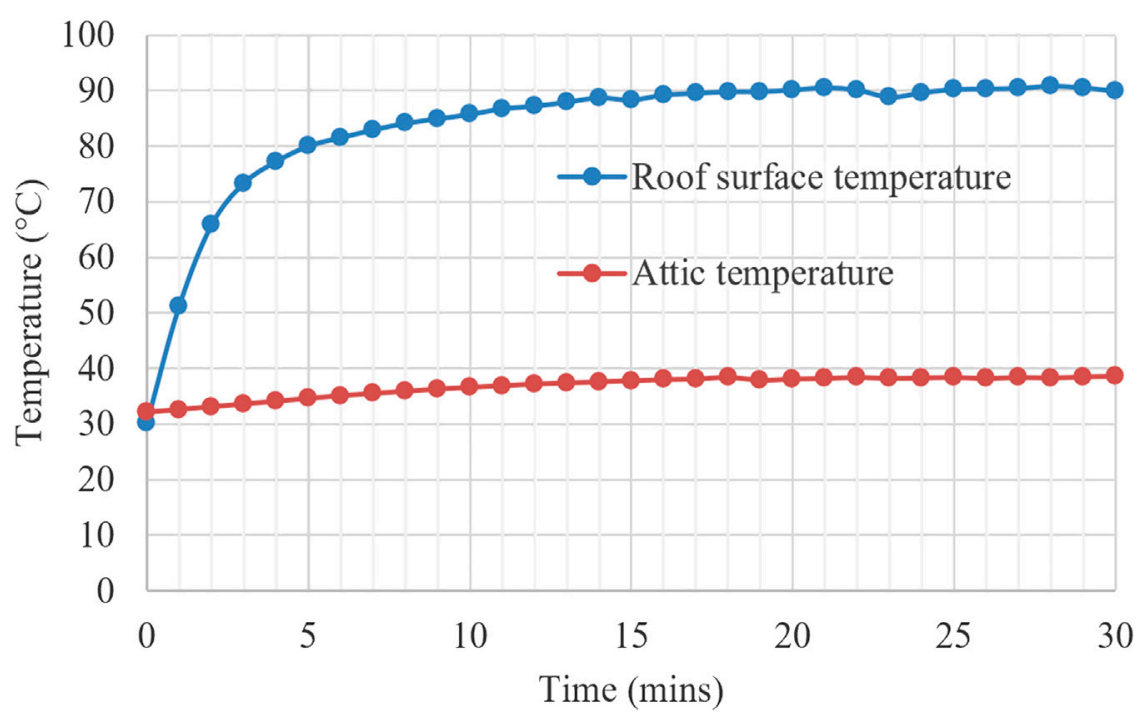

FIGURE 9 | Performance of metal deck roof.

$T_{\text {out }}=$ the outlet temperature at moving-air-cavity, $\mathrm{K}$

$T_{\text {in }}=$ the inlet temperature at moving-air-cavity, $\mathrm{K}$

\section{RESULTS AND DISCUSSION}

\subsection{Metal Deck Roof (Design I)}

The experiment was started with a controlled experiment roof model composed solely of a conventional red metal deck. Figure 9 shows the results obtained and presented in a graph of temperature vs. time for a total experiment duration of $30 \mathrm{~min}$.

Results show that the maximum temperatures of the roof surface and attic were $90.8^{\circ} \mathrm{C}$ and $38.6^{\circ} \mathrm{C}$, respectively. The roof temperature become constant after $13 \mathrm{~min}$ of testing. The maximum difference in temperature between the attic and roof upper surface was $51.3^{\circ} \mathrm{C}$ at $30 \mathrm{~min}$. The rate of roof temperature increase was $14.36^{\circ} \mathrm{C} / \mathrm{min}$ in the first $3 \mathrm{~min}$. The rapid increase was due to the low reflectivity and high thermal conductivity of the normal coating on the metal deck roof surface. The temperature increase rate proves the high thermal conductivity of the metal deck, which is at $44.8 \mathrm{~W} / \mathrm{mK}$ (Singh et al., 2016).

For attic temperature variation, the maximum of attic temperature was about $38.6^{\circ} \mathrm{C}$ at $30 \mathrm{~min}$ and the increase rate was $0.2167^{\circ} \mathrm{C} / \mathrm{min}$. This outcome is proven when the metal deck roof is used; the house structure is maintained as hot as the ambient temperature. The natural ventilation did not carry the heat away as the metal roof is like an opened roof, the heat can penetrate into the building directly and immediately.

\subsection{Foamed Concrete Roof (Design II)}

The experiment was continued with the metal roof removed and replaced with a lightweight foam concrete roof, a more practical roof design approach. Figure 10 shows the result obtained and presented in a graph of temperature vs. time for the roof Design II.

For the roof surface temperature, the temperature increased slowly throughout the experiment when the roof was replaced with foam concrete. The metal deck roofing had steep gradient, which is about $14.36^{\circ} \mathrm{C} / \mathrm{min}$ at the first $3 \mathrm{~min}$ when exposed to the spotlight. However, the lightweight foam concrete reached $1.65^{\circ} \mathrm{C} / \mathrm{min}$ only during the first $2 \mathrm{~min}$ of testing.

The maximum roof surface temperature achieved by foam concrete roof was $56.7^{\circ} \mathrm{C}$, which was $34.1^{\circ} \mathrm{C}$ lower than the metal roof. This can be proven by the foam concrete's lower thermal conductivity and thermal absorptivity. The foam concrete's thermal conductivity limits from 0.24 to $0.74 \mathrm{~W} / \mathrm{mK}$ due to the existence of voids (Ganesan et al., 2015). The roof is the major solar heat collector where $40 \%$ of the energy would be consumed for top-floor buildings; hence, the roof material is an essential element for the cool roofing system (Gao et al., 2017). By utilizing the lightweight foam concrete in the building design, it can reduce the amount of heat trapped at the roof surface.

For the attic temperature, the maximum temperature recorded was $36.0^{\circ} \mathrm{C}$, which was lower than the metal decks by $2.6^{\circ} \mathrm{C}$. The average increase rate of attic temperature was $0.1267^{\circ} \mathrm{C} / \mathrm{min}$, which was lower than the metal decks by $0.09^{\circ} \mathrm{C} / \mathrm{min}$. Foam concrete roof is a better heat insulator than metal roof; hence, the attic region had a lower temperature increase rate despite the higher ambient temperature.

\subsection{Foam Concrete Roof With Moving-Air-Cavity (Design III)}

The experiment was continued with the implementation of MAC with foam concrete roof model. Figure 11 shows the result obtained and presented in a graph of temperature vs. time for roof Design III. 


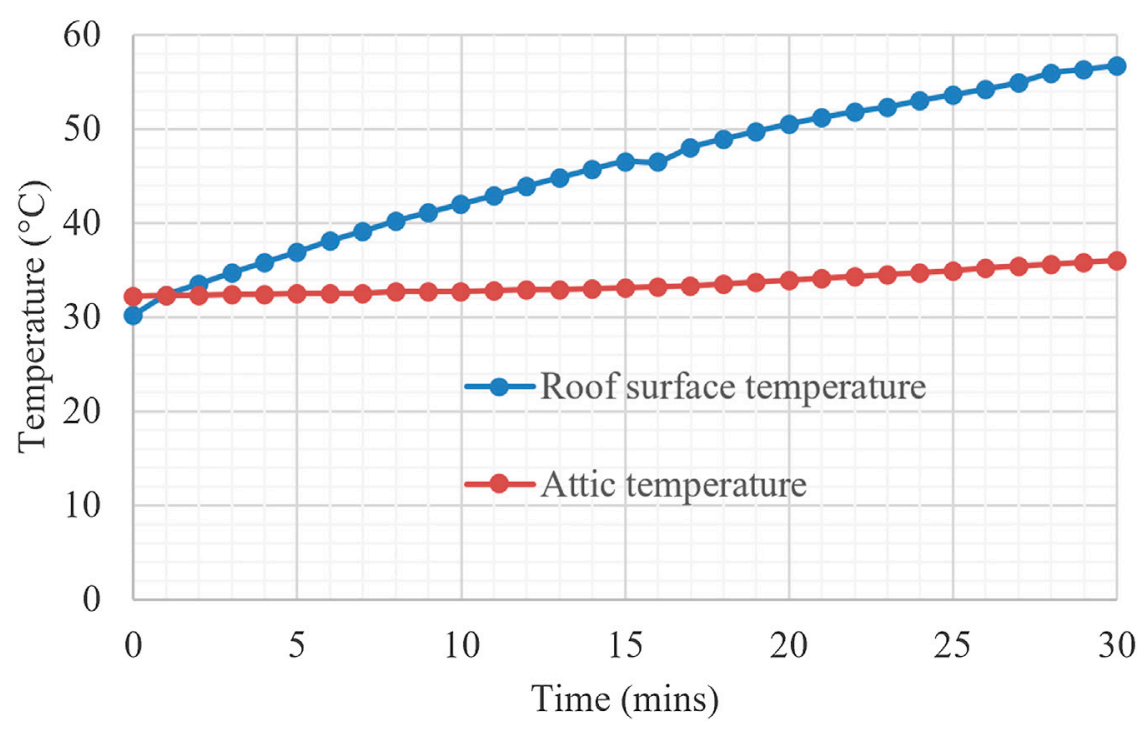

FIGURE 10 | Performance of lightweight foam concrete roof.

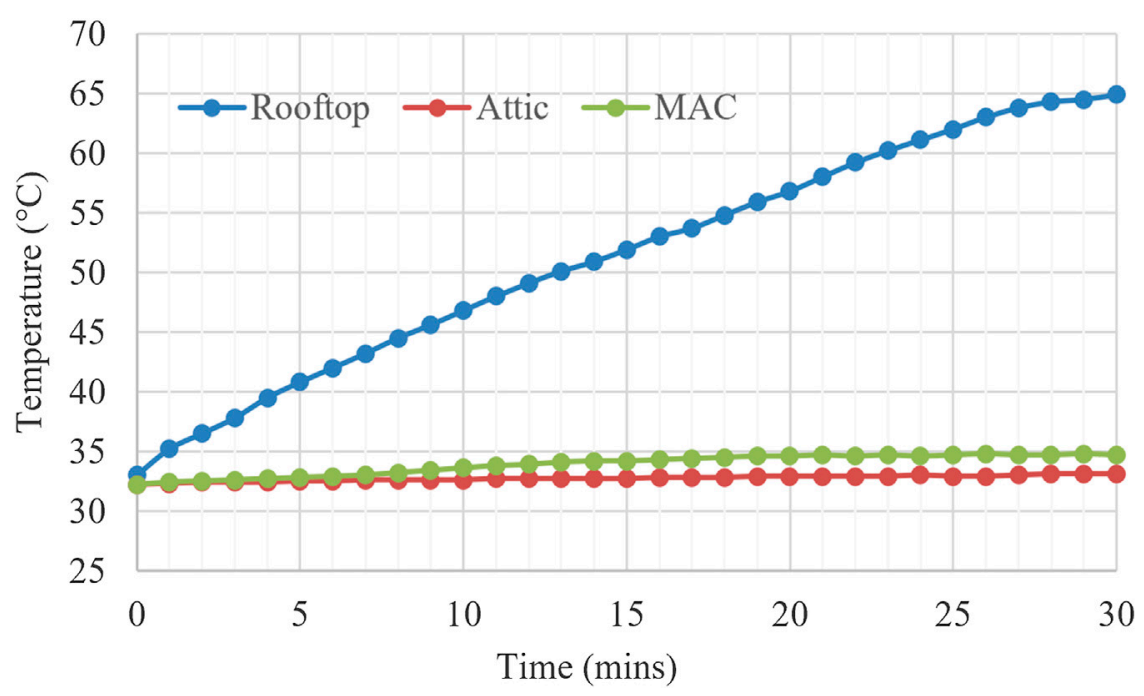

FIGURE 11 | Performance of lightweight foam concrete roof with MAC.

The roof surface temperature increased slowly as shown in Figure 11 due to the low thermal conductivity of foam concrete and reached a maximum recorded temperature of $67.0^{\circ} \mathrm{C}$ and increased rate of $1.1333^{\circ} \mathrm{C} / \mathrm{min}$. The maximum recorded temperature was $23.8^{\circ} \mathrm{C}$, which was $11.1^{\circ} \mathrm{C}$ lower than that of the metal decks. The highest attic temperature recorded was $33.1^{\circ} \mathrm{C}$, which was $2.9^{\circ} \mathrm{C}$ lower than that of the foam concrete without MAC. For the attic temperature, the average increase rate of $0.03^{\circ} \mathrm{C} / \mathrm{min}$ was $0.0967^{\circ} \mathrm{C}$ / min lower than that of the foam concrete without MAC.

By adding the MAC underneath the foam concrete roof, the average attic temperature increase rate showed a decrease of $76.32 \%$. This proved the efficiency of MAC's parallel radiative air cooler in promoting the heat transmission and flowing rate. With this high emissive material, the heat is transferred back to the surrounding continuously, which then executed the passive cooling (Chen and Lu, 2020).

\subsection{Foam Concrete Roof With Moving-Air-Cavity and Solar-Powered Fans (Design IV)}

The experiment was continued with the implementation of solarpowered fans integrated with MAC and lightweight foam concrete roof. Figure 12 shows the results obtained and presented in a graph of temperature vs. time for roof Design IV.

For roof surface temperature, the maximum temperature recorded was $63.9^{\circ} \mathrm{C}$ for roof Design $\mathrm{IV}$, which was $3.1^{\circ} \mathrm{C}$ 


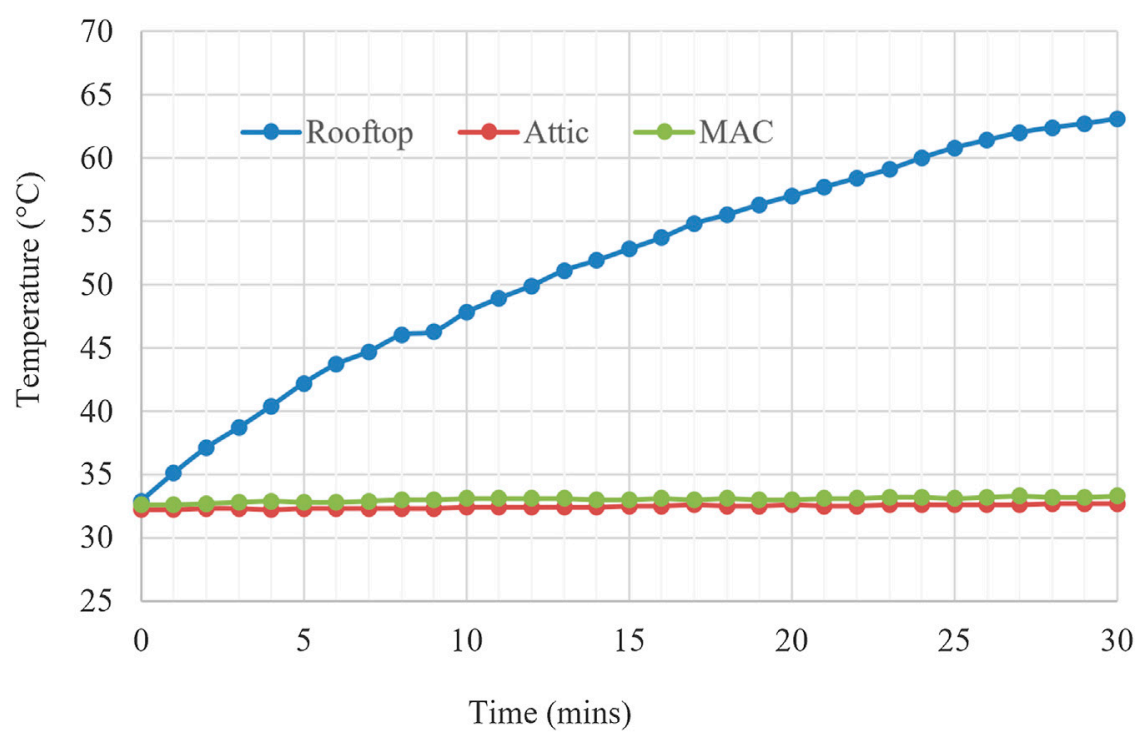

FIGURE 12 | Performance of lightweight foam concrete roof with MAC and solar-powered fans.

lower than that of roof Design III. The roof temperature increase rate was $1.0333^{\circ} \mathrm{C} / \mathrm{min}$, which was $0.01^{\circ} \mathrm{C} / \mathrm{min}$ lower than that of roof Design III. The highest recorded attic temperature and the average attic temperature increase rate were $32.7^{\circ} \mathrm{C}$ and $0.0167^{\circ} \mathrm{C} /$ min, which were $0.4^{\circ} \mathrm{C}$ and $0.0133^{\circ} \mathrm{C} / \mathrm{min}$ lower than the roof without solar-powered fans.

At this experiment, three halogen spotlights were used instead of two spotlights as in the previous experiment due to the third spotlight being used to supply solar power to solar-powered fans. The low attic temperature had proved the efficiency of solarpowered fans with an expected airflow rate of $0.68 \mathrm{~m} / \mathrm{s}$ in removing the heat at the air channel inside of MAC to keep the attic cool (Yew et al., 2018).

Moreover, the attic temperature increase rate had shown a decrease of $92.29 \%$ when compared with the normal metal roof. This amount of decrease had improved by $15.97 \%$ when solarpowered fans were implemented in this MAC. Air circulation is important in keeping the attic cool by channeling out the heat (Sun et al., 2013). Solar-powered fans had successfully kept the model cool and maintained at a temperature lower than the ambient by active approach with the combination of the thermal break at the MAC.

\subsection{Variation of Attic Temperature of All Roof Design Models}

Results show that the attic temperature increased rapidly when metal deck roof was applied in roof Designs I. Then, when foam concrete roof was applied solely in roof Design II without the MAC and solar-powered fans, the attic temperature increased slower but did not set down at any temperature, although the gradient is lower than the metal deck roof. However, after the MAC was introduced at roof Design III, the attic temperature performed a steady variation. Table 1 shows the average attic temperature increasing rate for each of the roof designs.
Without the MAC, the lightweight foam concrete roof solely had an average attic temperature increase rate of $0.1267^{\circ} \mathrm{C} / \mathrm{min}$. After the MAC was added, it dropped to $0.03^{\circ} \mathrm{C} / \mathrm{min}$, which was a decrease of $76.32 \%$. The MAC promoted passive radiative cooling. Passive radiative cooling dissipated extra heat to the surroundings through the structure's outlet without the need for power input (Liu, et al., 2020). The material of silver coating on the aluminum foil possessed $97 \%$ of solar reflectivity and $96 \%$ of infrared emissivity (Gentle and Smith, 2015). In this experiment, passive radiative cooling was achieved by silver color coating on the aluminum sheet in the MAC. Heat is dissipated and removed effectively from MAC due to the fantastic heat emissivity characteristics of MAC.

Without the solar-powered fans, the average attic temperature increase rate was $0.03^{\circ} \mathrm{C} / \mathrm{min}$ in roof Design III. After the solarpowered fans were added in roof Design IV, it fell to $0.0167^{\circ} \mathrm{C} / \mathrm{min}$. The solar-powered fans work as the active cooling system to improve the MAC ventilation. With the combination of passive radiative cooling and active solar-powered fans, the attic temperature achieved the lowest temperature increase rate at $0.0167^{\circ} \mathrm{C} / \mathrm{min}$ for roof Design IV.

\subsection{Summary of the Performances of the Different Roof Model Designs}

The conventional metal deck roof was compared with a new cool roof system. The cool roofing system combined the integration of foam concrete roof with the implementation of MAC and solar-powered fans. The MAC implemented a high reflectivity surface, which promoted radiative cooling. The solar-powered fans had improved the mass flow of air for better heat transfer between ambient air and heat trapped in the roof. The performance of each roof design is summarized in Table 2. The roof Design IV had the lowest attic temperature and maintained the coolest attic among all roof models.

The metal deck roof model showed the highest roof surface temperature of $90.8^{\circ} \mathrm{C}$. The metal deck roof was then replaced by 
TABLE 1 | The average attic temperature increase rate for different roof designs.

TABLE 2 | Summary of the performances of the different roof designs.

\section{Roof design}

Type of roof

Utilize MAC

Utilize solar-powered fans

Maximum roof surface temperature $\left({ }^{\circ} \mathrm{C}\right)$

Maximum attic temperature $\left({ }^{\circ} \mathrm{C}\right)$

I

Metal

No

No

90.8

38.7
II

Foam concrete

No

No

56.7

36.0
III

Foam concrete

Yes

No

67.0

33.1
IV

Foam concrete

Yes

Yes

63.9

32.7 foam concrete roof, which has reduced the attic temperature by up to $2.7^{\circ} \mathrm{C}$ from $38.7^{\circ} \mathrm{C}$ to $36.0^{\circ} \mathrm{C}$. This proved that the ability of lightweight foam concrete roof performed as the roof insulator due to its lower thermal conductivity. The heat is transferred slower in foam concrete tile, which has lesser heat conducted through the roof and enter the attic region.

Then, the MAC was installed underneath the foam concrete roof. The attic temperature then further reduced the attic temperature up to $2.9^{\circ} \mathrm{C}$ (from $36^{\circ} \mathrm{C}$ to $33.1^{\circ} \mathrm{C}$ ) compared with the foam concrete roof without the MAC. The roof design with MAC showed a decrease of $5.6^{\circ} \mathrm{C}$ in the attic region compared with the original metal roof. MAC's radiative silver surface of high emissivity properties increases the heat dissipation rate, thus acting as the passive radiative cooling.

Last, the solar-powered fans were introduced at the inlets of $\mathrm{MAC}$, which further reduced the attic temperature by $6.0^{\circ} \mathrm{C}$ (from $38.7^{\circ} \mathrm{C}$ to $32.7^{\circ} \mathrm{C}$ ) compared with the normal metal roof. The maximum attic temperature achieved was $32.7^{\circ} \mathrm{C}$. Solar-powered fans were the active cooling approach by increasing the mass of air in the air channel and promoting the dynamic air circulation. The heat is thus removed through the air channels in MAC effectively with the integration of the active cooling. This roof design with foam concrete roof integrated with MAC and solarpowered fans performed the most stable and coolest attic temperature. The attic temperature remained unchanged for the last $10 \mathrm{~min}$, and it is the only roof design with this stabilizing performance that keeps the attic cool. The mechanism of the heat transfer of the integrated cool roof system is described in the Section 2.7 for more details.

\section{CONCLUSION}

In this project, the main objective is to design an integration cool roof system to reduce the temperature in the attic by using effective roofing materials, MAC ventilation, and sustainable solar. A total of four roof design models with different active and passive cool roof systems were fabricated and carried out indoors. The combination of lightweight foam concrete roof, MAC, and solar power demonstrated the best performance among these four cool roof models. A total temperature reduction of about $6^{\circ} \mathrm{C}$ in the attic is achieved compared with a normal metal deck roofing (Design I). In addition, integration of MAC-solar powered fans had resulted in the reduction of about $2.9^{\circ} \mathrm{C}$ compared with the MAC system. In general, the combination of lightweight foam concrete roof with MAC and solar-powered fans has proven to be effective in improving the comfort of building occupants with the passive and active cooling approaches.

\section{DATA AVAILABILITY STATEMENT}

The raw data supporting the conclusions of this article will be made available by the authors, without undue reservation.

\section{AUTHOR CONTRIBUTIONS}

MY supervised the project. $\mathrm{MH}$ conducted the experimental work. MH wrote the original manuscript. MY and LS analyzed and edited the manuscript. MY proofread the manuscript. All authors contributed to the manuscript revision and approved the submitted version of the manuscript.

\section{FUNDING}

Funding from Final Year Project budget.

\section{ACKNOWLEDGMENTS}

We gratefully acknowledge the laboratory facilities support and final year project funding from Lee Kong Chian, Faculty of Engineering and Science, Universiti Tunku Abdul Rahman. 


\section{REFERENCES}

Bianchini, F., and Hewage, K. (2012). How "green" are the green roofs? Lifecycle analysis of green roof materials. Build. Environ. 48, 57-65. doi:10.1016/j. buildenv.2011.08.019

Chen, J., and Lu, L. (2020). Comprehensive evaluation of thermal and energy performance of radiative roof cooling in buildings. J. Build. Eng. 33, 101631. doi:10.1016/j.jobe.2020.101631

Ganesan, S., Othuman Mydin, M. A., Mohd Yunos, M. Y., and Mohd Nawi, M. N. (2015). Thermal properties of foamed concrete with various densities and additives at ambient temperature. Appl. Mech. Mater. 747, 230-233. doi:10. 4028/www.scientific.net/AMM.747.230

Gao, Y., Shi, D., Levinson, R., Guo, R., Lin, C., and Ge, J. (2017). Thermal performance and energy savings of white and sedum-tray garden roof: a case study in a Chongqing office building. Energy Build. 156, 343-359. doi:10.1016/j.enbuild.2017.09.091

Gentle, A. R., and Smith, G. B. (2015). A subambient open roof surface under the mid-summer sun. Adv. Sci. 2 (9), 1500119. doi:10.1002/advs.201500119

Hasan, A. F. (2017). Smarter consumers malaysia volume 11. Available at: https:// www.st.gov.my/ms/contents/publications/energyMalaysia/Energy (Accessed April 19, 2020).

Liu, J., Zhang, D., Jiao, S., Zhou, Z., Zhang, Z., and Gao, F. (2020). Preliminary study of radiative cooling in cooling season of the humid coastal area. Sol. Energy Mater. Sol. Cell. 208, 110412. doi:10.1016/j.solmat.2020.110412

Macintyre, H. L., and Heaviside, C. (2019). Potential benefits of cool roofs in reducing heat- related mortality during heatwaves in a European city. Environ. Int. 127, 430-441. doi:10.1016/j.envint.2019.02.065

Ooi, J. B., Lockard, C. A., Leinbach, T. R., and Ahmad, Z. B. (2020). Malaysia facts, geography, history, and points of interest britannica [Online]. Available at: https://www.britannica.com/place/Malaysia (Accessed April 19, 2020).

Romeo, C., and Zinzi, M. (2013). Impact of a cool roof application on the energy and comfort performance in an existing non-residential building. A Sicilian case study. Energy Build. 67, 647-657. doi:10.1016/j.enbuild.2011.07.023
Singh, M., Gulati, R., Srinivasan, R., and Bhandari, M. (2016). Three-dimensional heat transfer analysis of metal fasteners in roofing assemblies. Buildings 6 (4), 49. doi:10.3390/buildings6040049

Sun, Y., Wang, S., and Xiao, F. (2013). Development and validation of a simplified online cooling load prediction strategy for a super high-rise building in Hong Kong. Energy Convers. Manag. 68, 20-27. doi:10.1016/j.enconman.2013.01.002

Yew, M. C., Ramli Sulong, N. H., Chong, W. T., Poh, S. C., Ang, B. C., and Tan, K. H. (2013). Integration of thermal insulation coating and moving-air-cavity in a cool roof system for attic temperature reduction. Energy Convers. Manag. 75, 241-248. doi:10.1016/j.enconman.2013.06.024

Yew, M. C., and Yew, M. K. (2021). "Chapter: 12-Active and passive systems for cool roofs," in Fernando pacheco-torgal, lech czarnecki, anna laura pisello, luisa F. Cabeza, claes-göran GranqvistWoodhead publishing series in civil and structural engineering. Eco-efficient materials for reducing cooling needs in buildings and construction. (Oxford, United Kingdom: Woodhead Publishing), 275-288.

Yew, M. C., Yew, M. K., Saw, L. H., Ng, T. C., Chen, K. P., Durairaj, R., et al. (2018). Experimental analysis on the active and passive cool roof systems for industrial buildings in Malaysia. J. Build. Eng. 33, 134-141. doi:10. 1016/j.jobe.2018.05.001

Zhao, D., Aili, A., Yin, X., Tan, G., and Yang, R. (2019). Roof-integrated radiative air-cooling system to achieve cooler attic for building energy saving. Energy Build. 203, 109453. doi:10.1016/j.enbuild.2019.109453

Conflict of Interest: The authors declare that the research was conducted in the absence of any commercial or financial relationships that could be construed as a potential conflict of interest.

Copyright $\odot 2021$ Yew, Yew, Ho and Saw. This is an open-access article distributed under the terms of the Creative Commons Attribution License (CC BY). The use, distribution or reproduction in other forums is permitted, provided the original author(s) and the copyright owner(s) are credited and that the original publication in this journal is cited, in accordance with accepted academic practice. No use, distribution or reproduction is permitted which does not comply with these terms. 